\title{
COUNTERPOINT: REPLY TO ORRENIUS AND ZAVODNY
}

Vernon M. Briggs, Jr.

On the fundamental conclusions, the positions argued by Pia Orrenius and Madeline Zavodny and my own are in essential agreement. The immigration policy of the United States is in dire need of changes. The public concern is, in their words, "driven by the increase in immigration in recent years, particularly of unauthorized immigration." Our mutual worries pertain to the disproportionately adverse impacts of the immigrant inflow on the nation's lowskilled work force and the high fiscal burden borne by local communities and states with growing immigrant populations.

The differences between the two papers center on the approaches taken to reach these conclusions and the policy reforms that flow from the respective analyses.

\section{General Comments}

The nation's immigration system at any given time is embodied in statutory laws; administrative rules, regulations and guidelines; enforcement practices, and court decisions all of which have evolved over the years from past experiences. Assessing the data generated from this institutional maze for the purposes of making policy recommendations is no easy feat (Briggs, 2005, pp. 177-193). Immigration scholars who rely heavily on the econometric literature and the assumptions of its ahistorical models, often make mistakes if they do not also recognize the importance of mastery of evolutionary policy influences and institutional practices on the analysis of policy outcomes.

Unfortunately, Orrenius and Zavodny make just such an error. It is one that does, in fact, have explanative significance for understanding how the current immigration system of the United States got off-track starting in 1965. In the prelude to their recommendations for new reforms, they state: "Before immigration reform policy was overhauled in 1965, national origins limited migration from Asia and Latin America..." which led to European domination of "the small inflow of immigrants" over the 1921-1965 era. This is wrong. The national origins quota system, which was imposed by legislation in 1921 (temporarily) and in 1924 (permanently until repealed in 1965), never applied to any country in the Western Hemisphere (Briggs, 2003, pp. 82-83). Consequently, immigration from Mexico in particular and the Caribbean in general soared during the decade of the 1920s. Immigration from this region (as from 
elsewhere) did recede during the depression years of the 1930s (when unemployment rates were high) and the war years of the 1940s (when the military draft was in place); but it revived in the late 1940s and continued to do so up until passage of the Immigration Act of 1965.

Indeed, one of the most controversial reform features associated with the passage of the Immigration Act of 1965 was that it imposed a ceiling on Western Hemisphere immigration of 120,000 immigrants a year which went into effect July 1, 1968 (Briggs, 2003, pp. 126-127; 130-131). It was the first numerical restriction ever placed on immigrants from the Western Hemisphere in U.S. history. There were no quota restrictions placed on immigration from any individual nation in the Western Hemisphere until 1976. That year, the country ceiling of 20,000 legal immigrants a year that had also been introduced in 1965 to apply to all nations in the Eastern Hemisphere, was applied for the first time to the nations of the Western Hemisphere as well.

The country most heavily impacted by both of these legislative changes was Mexico (which up until this time accounted for most of the legal immigration from the entire Western Hemisphere). These legislative enactments - done in the name of providing equal treatment to all countries-- led to massive backlogs of immigrant admissions from Mexico in the ensuing years. These backlogs are widely believed to have contributed to the explosion of illegal immigrants from that country that occurred during those years and which has continued to this day.

More importantly, the number of immigrants from Latin America over the timespan -- when the national origins admission system was only in effect for countries in the Eastern Hemisphere -- largely explains the unanticipated twist in the source countries of immigrants that has followed passage of the Immigration Act of 1965 . When the national origins admission system was terminated in 1965 , it was replaced with the new system that favored reunification of the extended family. Under this scenario, the most favored countries to be sources of legal immigrants in the post-1965 era would be those immigrants living in the United States who came from countries not numerically restricted in the 19211965 era (i.e., those from Latin America, Mexico in particular) and who still had living family relatives back in their homelands. 


\section{Specific Comments}

Orrenius and Zavodny see immigration as essentially an "economic benefit" for the United States even though they acknowledge that the research shows these benefits to be "just a tiny fraction of GDP"(i.e., Gross Domestic Product). They do acknowledge that there are "distributional issues" pertaining to who gains and who loses but they feel that they could be offset by policy changes rather than by reducing immigration.

Acknowledging that there is a need to find a better way to admit legal immigrants, Orrenius and Zavodny never say what they would do to change any of the existing family-reunification admission provisions. Instead, they focus on current employment-based admission slots for legal immigrants plus the various non-immigrant visas available for foreign workers to use on a temporary basis. They propose an auction-based system to replace both of these work-based systems. Such an allocation system would be similar to those currently used by the federal government to auction such commercial items as "Treasury securities, offshore oil leases, and the wireless spectrum." Auction prices reflecting market conditions would dictate who is selected. It is not clear how many would-be workers could be admitted under such a system or how the proposed system could be reconciled with actual labor market conditions at the local, regional or national levels. The prevailing system does at least have some certification requirements that seek to relate admissions and visa slots to actual labor market conditions. Presumably, such auctions could not be used to replace striking workers but could they be used to prevent unionization efforts? As proposed, these workers would be only issued "provisional work permits and visas," so what happens if they become unemployed or injured on or off the job? Who is going to oversee the administration and supervision of such workers while they are in this status flux?

Aside from a myriad of administrative matters and the basic fact of life that politicians will never surrender their right to use immigration policy as an instrument for political maneuvering, the major criticism of the use of such a system is the moral issue. Years ago, the labor movement of the United States was placed under the nation's antitrust laws by a series of dubious U.S. Supreme Court decisions that threatened their actual existence, Congress responded by passing the Clayton Antitrust Act of 1914 (15 U.S.C. 17). It has a famous Section 6 that proclaims: "The labor of human beings is not a commodity or article of commerce." Explicitly, this provision granted labor unions an exemption from 
the antitrust laws; implicitly, it established the principle that laws that are created to regulate product market activities - such as the use of auction systems - have no place being used to regulate human activities.

When it comes to their "distributional" concerns for who loses under the existing system, Orrenius and Zavodny have little to say. They propose to give an amnesty to the current 11.2 million illegal immigrants in the country. While this is an expedient way to wipe clear the number of illegal immigrants in the country, it is not the right way. It is a devastating proposal for citizen low-wage workers as it legitimizes the presence of the 8 million illegal immigrant workers in the labor force and it would now free them legally to seek work anywhere. All amnesty recipients, in turn, would be able to use their newly acquired status to enable millions of their relatives (also likely to be largely unskilled persons) to unify with their families over the following years. Moreover, amnesty does nothing to end the inflow of more illegal immigrants in the future-indeed, it encourages more to come. Hence, the burdens of wage suppression, job competition, and community service accommodation will continue to be borne by low skilled work force and their families-- even more so than now. It also means that native-born taxpayers and naturalized citizens must continue to pay more taxes and receive fewer benefits themselves in order to cover the costs of millions of people who should not even be in the country. Lastly, of course, it is a slap in the face to the more than 4 million persons who are currently waiting in lengthy queues to legally immigrate by policymakers who, once more, favor rewarding the lawbreakers who butted in-line in front of them.

Furthermore, Orrenius and Zavodny entirely ignore policy issues related to the number of refugee and political asylum seekers who also become participants in the nation's labor force. Their ranks also influence the research data contained in the immigration literature.

\section{The Alternative}

The U.S. Commission on Immigration Reform saw policy outcomes that seemed incongruent with the national interest and proposed policy changes. The fact that existing policies are resulting in a disproportionately large number of immigrants with low levels of human capital mean that those segments of nation's labor force and population who also have low human capital endowments are disproportionately bearing the burden of policy accommodation. It also concluded that the associated increases in immigrantrelated fiscal costs were falling disproportionately on the taxpayers of those 
local communities and states with growing immigrant numbers. The answer, therefore, is to reduce the annual scale of immigrant entries (a response that is even more germane in the context of the prolonged economic downturn that has been in place since mid-2008); end the extended family provisions that contribute to the chain migration effect associated with the family-reunification admission categories; ban unskilled immigration form the employment-based immigration admission categories; repeal the diversity lottery; cap refugee admissions; and take seriously the enforcement of our immigration laws.

If these policy measures were implemented and enforced, the negative features of the nation's immigration policies would be significantly mitigated. Under these circumstances, the "yardstick" set by the Commission for the nation to know whether or not it has "a credible immigration policy" could finally be realized: "people who should get in, do get in; people who should not get in, are kept out; and people judged deportable are required to leave" (U.S. Commission, 1997, p. xvi).

\section{References}

Briggs, Jr., V.M. (2003). Mass Immigration and the National Interest. Armonk, (NY): M.E. Sharpe.

. (2009). The State of U.S. Immigration Policy: The Quandary of Economic Methodology and the Relevance of Economic Research to Know. The Journal of Law, Economics \& Policy. Arlington (Va.): George Mason University School of Law

U.S. Commission on Immigration Reform. (1997). Becoming an American: Immigration and Immigrant Policy. Washington, DC: U.S. Commission on Immigration Reform. 